\section{Anterior Open Bite Treatment with Zygomatic Anchorage in Adult Patient: A case report}

\section{Erişkin Hastada Ön Açık Kapanışın Zygomatik Ankraj ile Tedavisi: Bir olgu sunumu}

\author{
Dr. Defne Çaldemir Yanık \\ Private Practice, Istanbul
}

Orcid ID: 0000-0001-9786-0741

Dt. Pınar Ünlü Kutay

Istanbul University, Faculty of Dentistry,

Department of Orthodontics, Istanbul.

Orcid ID: 0000-0002-4342-9689

Prof. Sönmez Fıratlı

Istanbul University, Faculty of Dentistry, Department of Orthodontics, Istanbul.

Orcid ID: 0000-0003-1071-1255

Received: 17 July 2018

Accepted: 23 January 2019

doi: 10.5505/yeditepe.2019.14622

Corresponding author:

Pınar Ünlü Kutay

İstanbul University, Faculty of Dentistry

Fatih/ İstanbul - Turkey

Phone: +905377304078

E-mail: punlukutay@istanbul.edu.tr

\section{SUMMARY}

This case report presents a dental class II malocclusion with anterior open-bite patient treated by zygomatic miniplates through the intrusion of maxillary posterior teeth. A 17-year-old female patient, whose chief complaint was anterior open bite, had a convex profile, retrusive chin, protrusive lips, flat smile arch. Intraoral examination showed Class II molar and canine relationship with $3 \mathrm{~mm}$ anterior openbite and dental crossbite in premolar region. Cephalometric tracings revealed a high angle vertical relationship, increased maxillary posterior dentoalveolar height, increased lower facial height, proclined upper and lower incisors. The treatment plan was intrusion of maxillary posterior teeth with acrylic splint type appliance by using zygomatic anchorage and fixed orthodontic mechanics. At the end of the treatment, due to molar intrusion and upward and forward rotation of mandible; anterior lower facial height and vertical dimensions of dentoalveolar complex were decreased, convex profile and protrusive lips was improved, anterior openbite was corrected, Class I molar and canine relationship were achieved. Anterior open-bite treatment by using zygomatic miniplates, which provide skeletal anchorage to intrude the maxillary posterior teeth, is a versatile and an effective method.

Keywords: Anterior open bite, molar intrusion, zygomatic miniplate anchorage

\section{ÖZET}

$\mathrm{Bu}$ olgu bildirisinde zigomatik bölgeye yerleştirilen miniplaklar aracılığıyla maksiller posterior dişlerin intrüzyonu ile tedavi edilmiş dişsel sınıf II ve anterior ön açık kapanışın tedavisi sunulmuştur. Esas şikayeti ön açık kapanış olan 17 yaşındaki kadın hasta konveks profile, belirgin olmayan çene ucuna, önde konumlanmış dudaklara ve düz bir gülümseme hattına sahipti. Ağız içi incelemede $3 \mathrm{~mm}$ ön açık kapanışla birlikte sınıf II molar ve kanin ilişkisi, premolar bölgesinde dişsel çapraz kapanış mevcuttu. Sefalometrik analiz değerlerinde high angle iskeletsel yapı, artmış maksiller posterior dentoalveolar yükseklik ve alt yüz yüksekliği, artmış üst ve alt kesici eksen eğimleri tespit edilmiştir. Tedavi planı maksiller posterior dişlerin akrilik splint tip aparey üzerinden zigomatik bölgeye yerleştirilen miniplaklar aracılığıyla intrüze edilmesi ve ardından sabit ortodontik mekaniklerle tedavi edilmesi olarak belirlenmiştir. Tedavi ile elde edilen molar intrüzyonu sonunda mandibulanın saat yönünün tersi yönünde oto rotasyonu ile alt yüz yüksekliği ve dentoalveolar kompleksin dik yön boyutlarında azalma, konveks profil ve önde konumlanmış dudak görünümünde iyileşme, ön açık kapanışın düzeltilmesi ile birlikte sınıf I molar ve kanin ilişkisi sağlanmıştır. Ön açık kapanış tedavisinde iskeletsel ankraj ünitesi olan zigoma miniplaklarının uygulanması, kullanışlı ve etkili bir yöntemdir. 
Anahtar kelimeler: Molar intruzyonu, ön açık kapanış, zigomatik miniplak ankrajı.

\section{INTRODUCTION}

Anterior open bite etiology involves skeletal, dental and functional components. Long lower facial height, downward and backward mandibular rotation, excessive growth of dentoalveolar complex (especially in the region of the posterior maxillary molar), reduced anterior dentoalveolar vertical height, airway pattern related nasopharyngeal obstruction, tongue thrust or thumb sucking are possible etiological factors in anterior open bite malocclusion. ${ }^{1,2}$ Skeletal open bites are often related to the excessive vertical growth of the posterior maxillary molar. Conversely, dental anterior open bites are primarily due to reduced incisor dentoalveolar vertical height. The difference between these two types of open bites are reflected in the occlusal planes. Treatment strategies should adress the cause of malocclusion. Environmental factors such as thumb sucking or tongue thrust should be eliminated. ${ }^{1}$ Using high-pull headgear, bite blocks, vertical chin cup or functional appliances which lead to intrusion of posterior teeth or extrusion of anterior teeth are effective in growing patients. ${ }^{3}$ These methods proved to be effective in preventing passive eruption of posterior teeth. ${ }^{4,5}$ In nongrowing patients repositioning of maxilla with orthognathic surgery, to decrease anterior facial height and rotate mandible upward and forward, is an alternative treatment method which presents acceptable treatment outcomes and long-term stability. But orthognathic surgery procedures possess the risk of any surgical intervention. Therefore, clinicians tend to use temporary anchorage devices (TADs) more often if discrepancy is not too severe. With the application of titanium miniplates at the zygomatic buttress region, posterior intrusion of the maxillary dentoalveolar complex has become more common. 4,6-8 A major advantage of molar intrusion with TADs is the favorable skeletal changes that enhance a patient's dentofacial esthetic. ${ }^{1}$ This case report presents a dental class II malocclusion and anterior open bite treated with the intrusion of the maxillary posterior teeth by zygomatic miniplates.

\section{CASE REPORT}

\section{Diagnosis and Etiology}

A 17-year-old female patient, whose chief complaint was anterior open bite, was referred to our clinic. Etiology of anterior open bite was thumb sucking and use of pacifier up to 2,5 years and tongue thrust could still be observed. In clinical examination, convex profile, retrusive chin, protrusive lips, flat smile arch and 2,5 mm left shift of upper midline was determined. She had Class II molar and canine relationship with $3 \mathrm{~mm}$ anterior open bite and dental crossbite in premolar region (Figure 1).
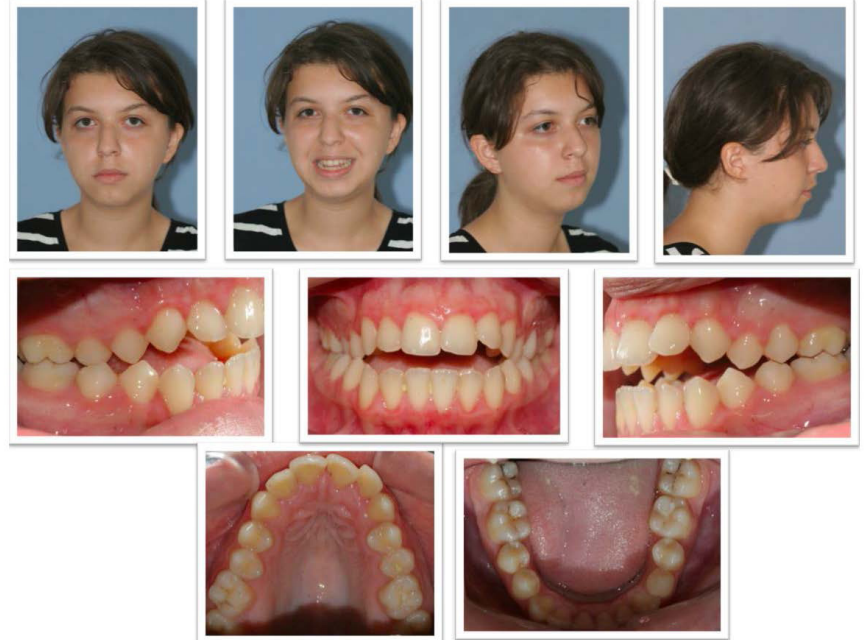

Figure 1. Pretreatment extra-oral and intra-oral photographs.

Transversal widths of maxilla were normal according to Ricketts PA analysis. The upper and lower arches were well aligned and had minimal arch length discrepancy. Cephalometric tracings revealed a high angle vertical relationship, increased maxillary posterior dentoalveolar height, increased lower facial height, proclined upper and lower incisors (Figure 2B, Table 1).

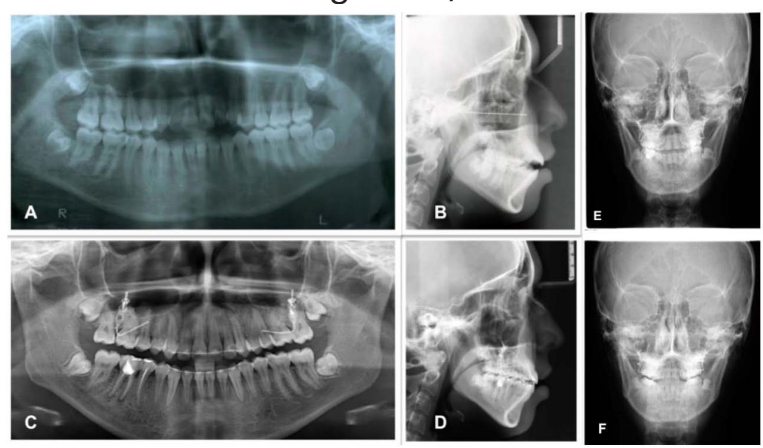

Figure 2. (A) pretreatment panoramic radiograph (B) pretreatment lateral cephalo metric radiograph (C) posttreatment panoramic radiograph (D) posttreatment lateral cephalometric radiograph (E) pretreatment PA radiograph (F) posttreatment PA radiograph

\section{Treatment Objectives}

The objectives of the treatment were to decrease maxillary posterior dentoalveolar height, eliminate anterior open bite, correct molar/canine relation, achieve ideal overjet and overbite, improve facial aesthetics through autorotation of the mandible by intrusion of maxillary posterior teeth with acrylic splint type appliance by using zygomatic anchorage and fixed orthodontic mechanics.

Treatment Progress

Zygomatic plate placement surgery was performed afterwards acrylic splint was cemented (Figure 3).
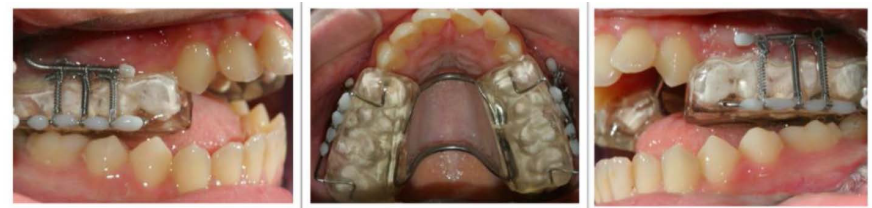

Figure 3. Appliance design

Acrylic splint covers maxillary premolars and molars bilaterally, segments are connected with palatal bars. Force system with three closed coil springs in each segment, 
which transferred $300 \mathrm{~g}$ initially and later $450 \mathrm{~g}$ was applied. Coils were measured monthly, and activated if necessary. Posterior intrusion was achieved in 8 months (Figure 4)
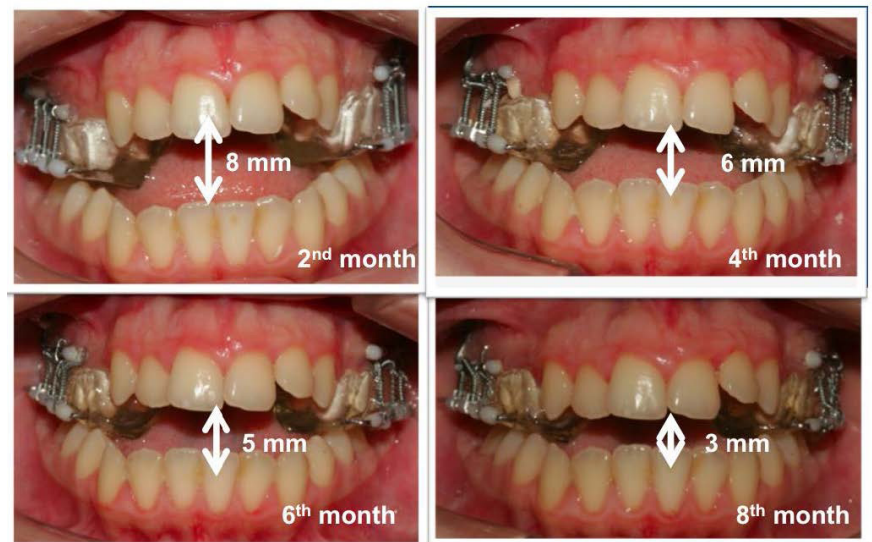

Figure 4. Stages of intrusion

and resulting overbite was $1 \mathrm{~mm}$. After removal of the acrylic appliance, fixed orthodontic treatment was initiated with the placement of brackets to maxillary and mandibular teeth (0.022" slot, Damon prescription system). Damon form archwires with passive self ligation system are used to achieve dental expansion. Incisor brackets were placed $0,5 \mathrm{~mm}$ gingivally to extrude anterior segment. During fixed orthodontic treatment posterior dentoalveolar vertical control was provided with wire ligation from miniplates to molar tubes. Retention protocol was fixed lingual retainer and part time wear of open bite activator.

\section{Results}

Total treatment time was 30 months. At the end of the treatment, due to upward and forward rotation of mandible, anterior lower facial height and vertical dimensions of dentoalveolar complex were decreased and anterior open bite was corrected (Figure 2D, Figure 5, Figure 6). Profile and lip esthetics was improved. Class I molar and canine relationship with ideal overjet and overbite were achieved (Figure 5).
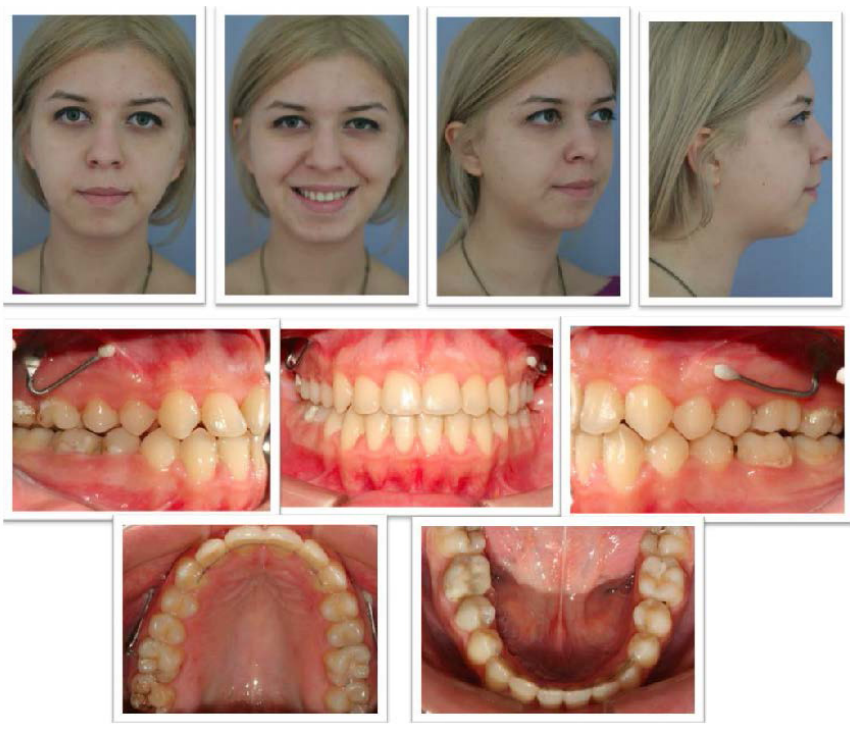

Figure 5. Posttreatment extra-oral and intra-oral photographs.
The post-treatment lateral cephalometric analysis showed decrease in vertical facial height, ANB angle and inclination of upper and lower incisors (Table 1, Figure 6).
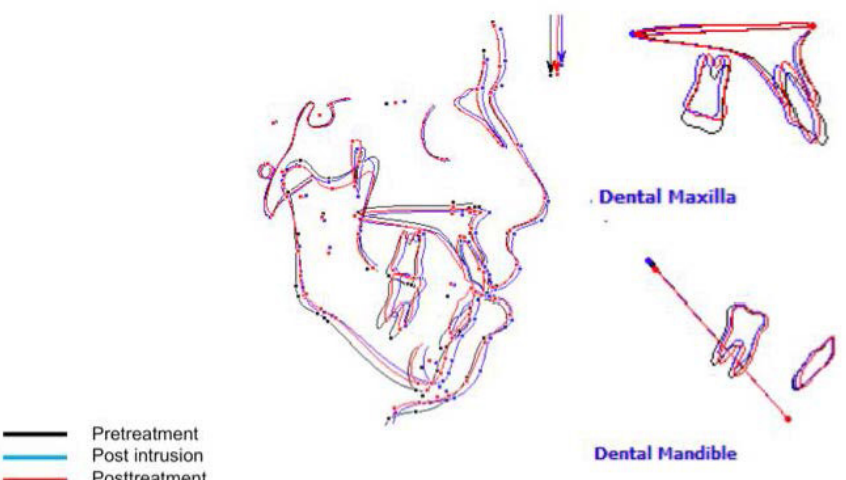

Figure 6. Cephalometric superimposition

Table 1. Cephalometric Summary

\begin{tabular}{|l|l|l|l|}
\hline & Pretreatment & Post intrusion & Posttreatment \\
\hline SNA angle & $80^{\circ}$ & $80^{\circ}$ & $80^{\circ}$ \\
\hline SNB angle & $77^{\circ}$ & $79^{\circ}$ & $79^{\circ}$ \\
\hline ANB angle & $3^{\circ}$ & $1^{\circ}$ & $1^{\circ}$ \\
\hline Witts & $+2,5$ & $+1 \mathrm{~mm}$ & $+1 \mathrm{~mm}$ \\
\hline SN-GoMe & $47^{\circ}$ & $42^{\circ}$ & $42^{\circ}$ \\
\hline Y axis & $72^{\circ}$ & $70^{\circ}$ & $70^{\circ}$ \\
\hline Jarabak Ratio & $\% 60$ & $\% 62$ & $\% 62$ \\
\hline U1/NA & $30^{\circ} / 8 \mathrm{~mm}$ & $29^{\circ} / 8 \mathrm{~mm}$ & $26^{\circ} / 7 \mathrm{~mm}$ \\
\hline L1/NB & $30^{\circ} / 8 \mathrm{~mm}$ & $29^{\circ} / 7 \mathrm{~mm}$ & $26^{\circ} / 6 \mathrm{~mm}$ \\
\hline Pg-NB & $1 \mathrm{~mm}$ & $1 \mathrm{~mm}$ & $1 \mathrm{~mm}$ \\
\hline Holdaway Ratio & $7 \mathrm{~mm}$ & $6 \mathrm{~mm}$ & $5 \mathrm{~mm}$ \\
\hline IMPA & $94^{\circ}$ & $93^{\circ}$ & $89^{\circ}$ \\
\hline NAPg & $148^{\circ}$ & $160^{\circ}$ & $160^{\circ}$ \\
\hline S line & $+3 /+6 \mathrm{~mm}$ & $+2 /+6 \mathrm{~mm}$ & $+2 /+4 \mathrm{~mm}$ \\
\hline
\end{tabular}

\section{DISCUSSION}

Tongue thrust is one of the etiologic factors which is related to open bite deformities. Etiology of anterior open bite in our patient was thumb sucking and use of pacifier up to 2.5 years. Subsequently tongue thrusting was developed and could still be observed at the time the patient presented for treatment. In tongue thrust, there is an imbalance between the perioral musculature and the tongue, which adversely affects the development of the anterior dentoalveolar complex and inhibits the normal eruption of teeth. Pre-treatment findings such as increased maxillary posterior height, anterior open bite and increased lower facial height were outcomes of the tongue thrust. Skeletal anchorage expands ranges of orthodontic treatment while treating dentofacial deformities. Miniplates provide absolute anchorage and can sustain higher force levels without the concern of failing. ${ }^{6,9}$ Anterior open bite is often caused by excessive growth of dentoalveolar complex. ${ }^{10}$ Intrusion of the over-erupted posterior teeth is an effective method to decrease the posterior maxillary dentoalveolar height. ${ }^{4,6}$ This case report represents the treatment of open-bite malocclusion with an acrylic splint type appliance that is anchored to two miniplates which 
are placed in the zygomatic buttress. To prevent molar tipping to buccal side, posterior teeth are surrounded by acrylic blocks and lateral segments of the appliance are connected by transpalatal bars.

Different force magnitudes have been applied to the maxillary posterior teeth, but there isn't any consensus in the literature for ideal intrusion force. Intrusion forces in previous studies were $300 \mathrm{~g}^{11} 400 \mathrm{~g}, 4,7,12450 \mathrm{~g}^{8}$ per side respectively. In our study, an initial intrusion force of $300 \mathrm{~g}$ followed by $450 \mathrm{~g}$ was applied. Total amount of intrusion, measured between first upper molar and palatal plane, was $2.3 \mathrm{~mm}$ after 8 months of treatment. Similar results were found in the previous studies. ${ }^{4,7,8,11-12}$ Intrusion of the posterior teeth using A-Ni-Ti coil springs, which maintain constant force during intrusion, provide an ideal force system. However, compared with the other types of tooth movement, intrusion occurs more slowly. ${ }^{2}$

Skeletal open-bite treatment by repositioning of maxilla, to decrease anterior facial height and rotate mandible upward and forward, has been commonly used. But these methods possess the risk that any surgical procedure does and are more likely for patients to refuse. With the use of temporary anchorage devices (TADs), it is possible to treat some patients with orthodontics alone. ${ }^{2,14} \mathrm{Com}$ pared with the orthognathic surgery, posterior intrusion with skeletal anchorage is an easier method for open bite treatment, but the severity of skeletal malocclusion should be evaluated carefully. Patients with class III malocclusion characterized by mandibular excess and long face with open bite deformity should be treated surgically and preferably by reducing the size of the mandible, as counterclockwise rotation of the mandible followed by molar intrusion should worsen the sagittal relationship of the jaws. ${ }^{13}$ In cases with mandibular deficiency, which requires both maxillary impaction and mandibular advancement surgery, orthognathic surgery treatment should be preferred rather than extensive orthodontics with TADs. But in less severe forms of skeletal class II malocclusion, if only maxillary surgery is sufficient, skeletal anchorage with orthodontics are more favorable. ${ }^{2}$

Miniscrews can also be used for anterior open bite treat ment. ${ }^{14,15}$ Through the use of miniscrews for intrusion of the upper and lower posterior teeth, similar rates of mandibular autorotation can be achieved as miniplates. ${ }^{16}$ However miniplates are more reliable compared to the miniscrews because of their distance from tooth roots. As intrusion occurs, miniscrews that extend through the gingiva may be in the way of tooth roots and cause root damage. Miniplates which are placed at the zygomatic buttress allow tooth movement without the risk of any root damage and provide more secure anchorage. ${ }^{2}$ Miniplates also provide absolute anchorage which can sustain orthopedic forces and are generally well-tolerat- ed by patients. ${ }^{17}$

As a result of the maxillary posterior intrusion, positive overbite with a leveled maxillary occlusal plane, improvement in soft tissue profile, increased chin projection and decrease in lower anterior facial height was achieved.

\section{CONCLUSION}

Anterior open bite treatment by using zygomatic miniplates, which provide skeletal anchorage to intrude the maxillary posterior teeth, is a versatile and an effective method.

\section{REFERENCES}

1. Uribe FA, Janakiraman $N$, Nanda R. Management of Openbite Malocclusion. In: Nanda R, Esthetics and Biomechanics in Orthodontics, 2nd edition. St. Louis, Elsevier, 2015

2. Proffit WR, Fields HW, Sarver DM. Contemporary Orthodontics. 4th edition. St. Louis: Mosby/Elsevier, 2006.

3. Freeman CS, McNamara JA Jr, Baccetti T, Franchi L, Graff TW. Treatment effects of the bionator and high-pull facebow combination followed by fixed appliances in patients with increased vertical dimensions. Am J Orthod Dentofacial Orthop 2007; 131: 184-95.

4. Erverdi N, Usumez S, Solak A, Koldas T. Noncompliance open-bite treatment with zygomatic anchorage. Angle Orthod 2007; 77: 986-990.

5. Kalra V, Burstone CJ, Nanda R. Effects of a fixed mag netic appliance on the dentofacial complex. Am J Orthod Dentofacial Orthop 1989; 95: 467-478.

6. Erverdi N, Usumez S, Solak A. New generation openbite treatment with zygomatic anchorage. Angle Orthod 2006; 76: 519-526.

7. Beycan K, Erverdi N. Anterior open-bite treatment by means of zygomatic miniplates: a case report. J Istanbul Univ Fac Dent 2017; 51: 52-56.

8. de Oliveira TFM, Nakao CY, Gonçalves JR, Santos-Pinto A. Maxillary molar intrusion with zygomatic anchorage in open bite treatment: lateral and oblique cephalometric evaluation. Oral and maxillofacial surgery 2015; 19: 71 77.

9. Daimaruya $T$, Nagasaka $H$, Umemori $M$, Sugawara J, Mitani $\mathrm{H}$. The influences of molar intrusion on the inferior alveolar neurovascular bundle and root using the skeletal anchorage system in dogs. Angle Orthodontist 2001; 71: 60-70.

10. Sassouni V. A classification of skeletal facial types. Am J Orthod 1969; 55: 109-123.

11. Scheffler NR, Proffit WR, Philips C. Outcomes and stability in patients with anterior openbite and long anterior face height treated with temporary anchorage devices and maxillary intrusion splint. Am J Orthod Dentofacial Orthop 2014; 146: 594-602.

12. Akan $S$, Kocadereli I, Aktaş A, Taşar F. Effects of maxillary molar intrusion with zygomatic anchorage on the 
stomatognathic system in anterior open bite patients. Eur J Orthod 2013; 35: 93-102.

13. Kuroda S, Sakai $Y$, Tamamura $N$, Deguchi $T$, Takano-Yamamoto T. Treatment of severe anterior open bite with skeletal anchorage in adults: comparison with orthognathic surgery outcomes. Am J Orthod Dentofacial Orthop 2007; 132: 599-605.

14. Togawa R, lino S, Miyawaki S. Skeletal class III and open bite treated with bilateral sagittal split osteotomy and molar intrusion using titanium screws. Angle Orthod 2010; 80: 1176-1184.

15. Foot R, Dalci O, Gonzales C, Tarraf NE, Darendeliler MA. The short-term skeleto-dental effects of a new spring for the intrusion of maxillary posterior teeth in open bite patients. Progress in Orthod 2014; 15:56.

16. Alsafadi AS, Alabdullah MM, Saltaji $H$, Abdo A, Youssef $M$. Effect of molar intrusion with temporary anchorage devices in patients with anterior open bite: a systematic review. Progress in Orthod 2016; 17:9.

17. Cornelis MA, Scheffler NR, Nyssen-Behets C, De Clerck HJ, Tulloch JF. Patients' and orthodontists' perceptions of miniplates used for temporary skeletal anchorage: a prospective study. Am J Orthod Dentofacial Orthop 2008; 133: 18-24. 